\title{
Effects of ovine follicular fluid on plasma LH and FSH secretion in ovariectomized ewes to indicate the site of action of inhibin
}

\author{
I. J. Clarke, J. K. Findlay, J. T. Cummins* and W. J. Ewens $\dagger$ \\ Medical Research Centre, Prince Henry's Hospital, St Kilda Road, Melbourne, Victoria 3004; \\ *Department of Neurosurgery, St Vincent's Hospital, Fitzroy, Victoria 3065; and $\uparrow$ Department of \\ Statistics, Monash University, Clayton, Victoria 3168, Australia
}

\begin{abstract}
Summary. Ovariectomized ewes were given $2 \mathrm{ml}$ s.c. injections of ovine follicular fluid (oFF) $(\mathbf{N}=3)$ or serum $(\mathbf{N}=3)$ and blood samples were collected each day for 3 days. Follicular fluid caused a significant $(P<0.005)$ reduction in FSH within 1 day, but did not affect mean LH values. Two groups of 3 ewes were treated as above but sampled intensively (each $10 \mathrm{~min}$ for $6 \mathrm{~h}$ ) on Days 1 (before treatment) and 4; mean plasma FSH concentration and plasma LH pulse frequency and amplitude were ascertained. Significant $(P<0.005)$ reduction of FSH concentration was seen in the oFF-treated ewes. A non-specific reduction in $\mathrm{LH}$ pulse amplitude, but not pulse frequency, was noted in the control ewes. This experiment was repeated with 2 groups of 4 ewes that were conditioned to the experimental environment and effects on LH secretion were not observed in the controls given serum. Treatment with oFF caused a $70 \%$ reduction $(P<0.005)$ in plasma FSH and a small $(30 \%)$ but significant $(P<0.005)$ reduction in mean $\mathrm{LH}$ concentrations. The latter was probably associated with a reduction in $\mathrm{LH}$ pulse amplitude in $3 / 4$ animals (N.S.) with no change in LH pulse frequency. Treatment with oFF, as in Exp. 1, caused a $95 \%$ reduction in $\mathrm{FSH}$ values and significant $(P<0.01)$ reduction $(32 \%)$ of $\mathrm{LH}$ pulse amplitude in ovariectomized ewes that had been subjected to hypothalamo-pituitary disconnection and in which gonadotrophin secretion was reinstated with pulses of $250 \mathrm{ng} \mathrm{GnRH}$ every $2 \mathrm{~h}$.

These results suggest that proteins from the sheep follicular fluid, including inhibin, act at the pituitary level to inhibit FSH secretion and may have some effects on LH pulse amplitude.
\end{abstract}

\section{Introduction}

Inhibin has been defined as a factor from the gonads which selectively inhibits the secretion of follicle stimulating hormone (FSH) from the pituitary gland (de Jong \& Robertson, 1985). That inhibin has a pituitary site of action is amply demonstrated by its action on pituitary cell cultures in vitro (Steinberger \& Steinberger, 1976; Baker et al., 1976; Lee et al., 1979; de Jong, Smith \& van der Molen, 1979; Scott, Burger \& Quigg, 1980). Whether or not inhibin has a hypothalamic action to limit the secretion of gonadotrophin-releasing hormone $(\mathrm{GnRH})$ is less certain. Intra-hypothalamic and intra-ventricular injections of inhibin containing material suppressed plasma FSH concentrations but the mechanism for this effect was not clear (Lumpkin, Negro-Vilar, Franchimont \& McCann, 1981; Condon, Leipheimer \& Curry, 1983). De Greef, de Jong, de Koning, Steenbergen \& van der Vaart (1983) sampled hypophysial portal blood in urethane-anaesthetized rats after a single treatment with a partly purified preparation of inhibin and found no effect on GnRH secretion within $6 \mathrm{~h}$. The possibility that longer term inhibin treatment could affect GnRH secretion has 
not been examined. High doses of inhibin are known to inhibit both FSH and LH release induced by GnRH injection into ovariectomized ewes (Findlay, Gill \& Doughton, 1985). Since LH pulses reflect GnRH secretion (Clarke \& Cummins, 1982), it is possible to assess, indirectly, the effects of high doses of inhibin on hypothalamic function by examining LH pulse frequency. McNeilly (1984) showed that follicular fluid from cows did not affect LH pulse amplitude or frequency during the early follicular phase of the sheep oestrous cycle. The interpretation of this study could be confounded by the effects of oestrogen which may increase GnRH pulse frequency at this time (Karsch, Foster, Bittman \& Goodman, 1983). Wallace \& McNeilly (1985) found that bovine follicular fluid increased LH pulse frequency during the luteal phase of the oestrous cycle of the ewe, an effect that could have been obtained indirectly by a reduction in oestrogen secretion and thus a decrease in oestrogen negative feedback.

We have sought clarification of the site of action of inhibin in vivo by measuring $\mathrm{LH}$ pulse frequency and amplitude before and after treatment of ovariectomized ewes with ovine follicular fluid (oFF). The pituitary effect of inhibin was defined in ovariectomized ewes that were subjected to hypothalamo-pituitary disconnection (Clarke, Cummins \& de Kretser, 1983) and given exogenous GnRH pulses to maintain gonadotrophin secretion. A preliminary account of this work has been presented (Clarke, Findlay \& Cummins, 1984b).

\section{Materials and Methods}

Animals. Mature Merino ewes were ovariectomized at least 1 month before experimentation by ventral midline incision under pentobarbitone-induced and halothane-maintained anaesthesia. The hypothalamic-pituitary disconnection procedure was performed under halothane anaesthesia, as previously described (Clarke et al., 1983). During experimentation the sheep were housed in individual pens and fed chaffed lucerne with free access to water. The studies were performed in late anoestrus (December).

Injection material. The source of inhibin was fluid aspirated from follicles of sheep ovaries collected at a local abattoir. Materials from two separate collections were used. The follicular fluid was charcoal-stripped and centrifuged according to the method of Tsonis et al. (1983) and then subjected to bioassay for inhibin potency (Scott et al., 1980; Lee, Quigg, McMaster; Burger \& Leversha, 1983) and oestrogen radioimmunoassay (Carson, Trounson \& Findlay, 1982). The inhibin potency of pool $1(\mathrm{oFF}-1)$ was $21100 \mathrm{U} / \mathrm{ml}(15700-28500,95 \%$ confidence intervals) and the potency of pool 2 (oFF-2) was $31500 \mathrm{U} / \mathrm{ml}(22700-38800,95 \%$ confidence intervals) (index of bioassay precision, $\lambda=0 \cdot 10$ ). Both preparations of oFF had an oestradiol-17 $\beta$ concentration of $0.2 \mathrm{nmol} / 1$. The stripped oFF was stored at $-15^{\circ} \mathrm{C}$ until used. Control animals were treated with serum from hypophysectomized ewes and had no detectable levels of inhibin $(<0.004 \mathrm{kU} / \mathrm{ml})$ or oestradiol-17 $\beta(<0.05 \mathrm{pmol} / \mathrm{l})$.

Experiment 1. This experiment was done to verify the result obtained by Findlay et al. (1985) especially with respect to the effect of oFF on LH concentrations. Groups of 3 ovariectomized ewes were given $2 \mathrm{ml}$ oFF-1 or $2 \mathrm{ml}$ control serum by s.c. injection beginning at 17:00 $\mathrm{h}$ on Day 1 and subsequently at $08: 30$ and 17:00 h on Days 2 and 3 and at $08: 30 \mathrm{~h}$ on Day 4. Blood samples were taken by jugular puncture each hour for $6 \mathrm{~h}$ between 10:00 and 15:00 h on Days 1, 2, 3 and 4. The plasma was harvested and stored at $-15^{\circ} \mathrm{C}$ for LH and FSH radioimmunoassay.

Experiment 2. The aim of this experiment was to examine the effects of oFF on plasma LH pulse frequency and amplitude, the hypothesis being that alterations in LH pulse frequency would be suggestive of alterations in GnRH pulse frequency. The experiment was done twice because there was a significant change in LH pulse amplitude with time in the serum-treated controls in Exp. $2 \mathrm{a}$. 
In Exp. 2a, two groups of 3 ovariectomized ewes were treated with oFF-1 or control serum as in Exp. 1. The sheep were brought in from pasture 3 days before the start of the experiment. Jugular venous catheters (Dwellcath; Tuta Labs Australia Pty Ltd, Sydney, Australia) were introduced and connected to $100 \mathrm{~cm}$ manometer lines (Portex Ltd, Hythe, Kent, U.K.). The manometer lines were closed with a 3-way tap and fixed to the sides of the animals' cages; blood samples could therefore be taken without disturbing the sheep. Jugular blood samples $(6 \mathrm{ml})$ were collected at 10 -min intervals between 09:00 and 15:00 h on Days 1 and 4. Plasma was harvested and stored at $-15^{\circ} \mathrm{C}$ until assayed for LH and FSH.

In Exp. 2b, sheep were housed and handled for 2 months before being used. These ovariectomized ewes were given s.c. injections of $2 \mathrm{ml} \mathrm{oFF}-2(\mathrm{~N}=4)$ or control serum $(\mathrm{N}=4)$ at 17:00 h on Day 1, at $08: 30$ and 17:00 $\mathrm{h}$ on Day 2 and at $08: 30 \mathrm{~h}$ on Day 3. The sheep were treated for 1 day less than those in Exp. 2a because of a shortage of ovine follicular fluid and the previous demonstration that oFF had a major effect on FSH by this time. Blood samples were collected (as above) on Days 1 and 3 and the plasma stored at $-15^{\circ} \mathrm{C}$ for LH and FSH assay.

Experiment 3. The aim of this experiment was to determine whether inhibin might act at the pituitary level to reduce $\mathrm{LH}$ responses to GnRH in vivo. Seven ovariectomized ewes that had also had a hypothalamo-pituitary disconnection received bilateral jugular venous catheters (Silastic tubing, Cat. No. 602-155; Dow Corning Corporation, Midland, MI, U.S.A.). One line was used for blood sampling and the other was connected by manometer line to an infusion pump. The infusion system which has been described previously (Clarke, Cummins, Findlay, Burman \& Doughton, 1984a) delivered $250 \mathrm{ng}$ pulses of $\mathrm{GnRH}$ in $2.25 \mathrm{ml}$ over $6 \mathrm{~min}$ every $2 \mathrm{~h}$. Infusions began 2 days after surgery for disconnection and the experimental period began after 11 days of GnRH replacement. Three sheep received oFF-1 injections s.c. at 17:00 h on Day 1 at 08:30 and 17:00 h on Days 2 and 3 and $08: 30 \mathrm{~h}$ on Day 4 , and 4 sheep received $2 \mathrm{ml}$ injections of control serum at the same times. Blood samples were collected each day between 09:55 and 15:00 h. Samples were taken 5 min before and 15,30 and $60 \mathrm{~min}$ after 3 consecutive GnRH pulses. Plasma was harvested and stored at $-15^{\circ} \mathrm{C}$ for LH and FSH assay.

Radioimmunoassays. Data for hormone assays were computed by the method of Burger, Lee \& Rennie (1972).

Plasma LH concentrations were obtained by the method of Lee et al. (1976) using NIH-LH-S18 as standard. All samples from a given sheep were assayed in the same run, and were read on that portion of the standard curve where the within-assay coefficient of variation $(\mathrm{CV})$ was $<20 \%$. The minimum within-assay CV was $3.8-6.4 \%$ between 7.4 and $11.6 \mathrm{ng} / \mathrm{ml}$ in 11 assays. Between-assay CV was $10 \%$ at $42 \mathrm{ng} / \mathrm{ml}$ and $7 \%$ at $6.6 \mathrm{ng} / \mathrm{ml}$. Assay sensitivity ranged from 0.2 to $0.6 \mathrm{ng} / \mathrm{ml}$.

Plasma FSH concentrations were obtained by the method of Bremner, Findlay, Lee, de Kretser \& Cumming (1980) using NIAMDD-FSH-S13 (biological potency $15 \times \mathrm{NIH}-\mathrm{FSH}-\mathrm{S} 1$ ) as standard. Samples were assayed and read as for LH (see above). The minimum within-assay CV was $2 \cdot 6-6.0 \%$ between 42 and $53 \mathrm{ng} / \mathrm{ml}$ and assay sensitivity was $1 \cdot 1-1 \cdot 8 \mathrm{ng} / \mathrm{ml}(\mathrm{N}=10)$. Between-assay $\mathrm{CV}$ was $5 \%$ at $64 \mathrm{ng} / \mathrm{ml}$ and $7 \%$ at $27 \mathrm{ng} / \mathrm{ml}$.

Analysis of data. In ovariectomized ewes LH pulses were defined as previously (Clarke \& Cummins, 1985). To calculate LH pulse amplitude we have taken the difference between the maximum value during a pulse and the value immediately before the start of a pulse. Inter-pulse interval was calculated as the time between successive peaks.

Statistics. It was desirable to compare changes in plasma hormone concentrations between two groups of animals when measurements were made before and during treatment and when more than one estimate was made in each animal on each day. To determine whether or not a decrease (one-sided test) with time was greater in treated animals than in controls, we used Student's $t$ statistic as follows: 
Let $A=$ sum of Day 1 averages

$B=$ sum of Day 4 averages

$C=B-A$

$D=\Sigma x^{2}$ for Days 1 and $4, x$ being a typical reading

$E=N\left[\Sigma \mathrm{a}^{2}\right]$ where $\mathrm{N}=$ number of values for each animal on each day and $a$ is the average reading on any day

$A^{\mathrm{i}}$ to $E^{\mathrm{i}}$ are corresponding values for treated animals

$G=\left(\left(D+D^{\mathrm{i}}\right)-\left(E-E^{\mathrm{i}}\right)\right) / 2(X+Y)(N-1)$ where $X$ is the number of controls and $Y$ is the number of treated animals.

Then $t=\left(\mathrm{C}-\mathrm{C}^{i}\right) /\{2 G(X+Y) / N\}$ with $2(X+Y)(N-1)$ degrees of freedom.

\section{Results}

\section{Experiment 1: effect of oFF on plasma FSH and LH concentrations}

Injection of $2 \mathrm{ml}$ oFF-1 caused a significant $(P<0.005)$ reduction in plasma mean FSH concentrations in ovariectomized ewes within 1 day (Table 1). Concentrations continued to decline

Table 1. Effects of oFF and control on plasma LH and FSH concentrations (means \pm s.e.m.) in ovariectomized sheep (Exp. 1)

\begin{tabular}{lccccc}
\hline & \multicolumn{2}{c}{$\begin{array}{c}\text { Plasma LH conc. } \\
(\mathrm{ng} / \mathrm{ml})\end{array}$} & & \multicolumn{2}{c}{$\begin{array}{c}\text { Plasma FSH conc. } \\
(\mathrm{ng} / \mathrm{ml})\end{array}$} \\
\cline { 2 - 3 } \cline { 5 - 6 } \cline { 5 - 6 } Day of exp. & $\begin{array}{c}\text { Control } \\
(\mathrm{N}=3)\end{array}$ & $\begin{array}{c}\text { oFF-1 } \\
(\mathrm{N}=3)\end{array}$ & & $\begin{array}{c}\text { Control } \\
(\mathrm{N}=3)\end{array}$ & $\begin{array}{c}\text { oFF-I } \\
(\mathrm{N}=3)\end{array}$ \\
\hline l (pretreatment) & $5 \cdot 5 \pm 0 \cdot 8$ & $8 \cdot 9 \pm 2 \cdot 2$ & & $46 \pm 7$ & $85 \pm 7$ \\
2 & $7 \cdot 4 \pm 0 \cdot 6$ & $7 \cdot 9 \pm 0 \cdot 9$ & & $51 \pm 9$ & $36 \pm 3^{* * *}$ \\
3 & $8 \cdot 0 \pm 1 \cdot 1$ & $7 \cdot 1 \pm 0 \cdot 8$ & & $52 \pm 9$ & $18 \pm 2^{* * *}$ \\
4 & $7 \cdot 5 \pm 2 \cdot 5$ & $5 \cdot 9 \pm 0.3$ & & $51 \pm 10$ & $12 \pm 2^{* * *}$ \\
\hline
\end{tabular}

*** Significant $(P<0.005)$ fall relative to Day 1 values and relative to the change in control values at the same time.

Table 2. Effects of oFF and control serum on mean ( \pm s.e.m.) plasma LH concentrations, LH pulse amplitude, LH inter-pulse interval and plasma FSH concentrations in ovariectomized ewes (Exp. 2)

\begin{tabular}{|c|c|c|c|c|c|c|}
\hline & \multicolumn{3}{|c|}{ Exp. 2a } & \multicolumn{3}{|c|}{ Exp. 2b } \\
\hline & $\begin{array}{c}\text { No. of } \\
\text { ewes }\end{array}$ & Day 1 & Day 4 & $\begin{array}{l}\text { No. of } \\
\text { ewes }\end{array}$ & Day I & Day 3 \\
\hline Control serum-treated e & & & & & & \\
\hline $\begin{array}{l}\text { Mean LH }(\mathrm{ng} / \mathrm{ml}) \\
\text { LH pulse }\end{array}$ & 3 & $8 \cdot 7 \pm 1 \cdot 5$ & $6.9 \pm 0.8^{*}$ & 4 & $7 \cdot 5 \pm 1.7$ & $8 \cdot 6 \pm 2 \cdot 0$ \\
\hline Amplitude (ng/ml) & 3 & $5 \cdot 2 \pm 1 \cdot 2$ & $2 \cdot 6 \pm 0.6^{*}$ & 4 & $6.5 \pm 1.0$ & $6.0 \pm 1.4$ \\
\hline Interval (min) & 3 & $41 \pm 2$ & $38 \pm 4$ & 4 & $54 \pm 5$ & $47 \pm 3$ \\
\hline Mean FSH $(\mathrm{ng} / \mathrm{ml})$ & 3 & $56 \pm 16$ & $58 \pm 15$ & 4 & $100 \pm 15$ & $99 \pm 16$ \\
\hline oFF-treated ewes & & & & & & \\
\hline $\begin{array}{l}\text { Mean LH }(\mathrm{ng} / \mathrm{ml}) \\
\text { LH pulse }\end{array}$ & 3 & $5.0 \pm 1.8$ & $2 \cdot 6 \pm 0.7$ & 4 & $5 \cdot 0 \pm 0 \cdot 3$ & $3.5 \pm 0.6 \dagger$ \\
\hline Amplitude (ng/ml) & 3 & $4 \cdot 2 \pm$ & $1 \cdot 2+0.2$ & 4 & $4 \cdot 6+$ & $3.6+$ \\
\hline Interval $(\min )$ & 3 & $38 \pm 3.0$ & $46 \pm 6$ & 4 & $51 \pm 4$ & $55 \pm 8$ \\
\hline Mean FSH (ng/ml) & 3 & $43 \pm 2 \cdot 0$ & 一 & 4 & $64 \pm 10$ & $19 \pm 9 \dagger$ \\
\hline
\end{tabular}

* Significantly $(P<0.005)$ lower than Day 1 values.

$\dagger$ Significant $(P<0.005)$ fall compared with controls at same time.

$\ddagger$ Not detectable. 
throughout the experiment and by Day 4 the values were $14 \%$ of those on Day 1. Mean plasma LH concentrations did not change significantly in these animals and neither did plasma LH nor FSH concentrations fall in the control ewes.

\section{Experiment 2: effects of oFF on plasma $L H$ concentrations}

Experiment $2 a$. After 3 days of oFF treatment, FSH was non-detectable in the plasma of the ovariectomized ewes; values did not change in control ewes (Table 2). There was a significant $(P<0.005)$ reduction in the mean plasma LH concentrations and the LH pulse amplitudes after 4 days of treatment with control serum (Fig. 1), indicating a non-specific effect. Mean plasma LH and LH pulse amplitudes in oFF-treated ewes fell by a similar amount (Table 2). The interval between LH pulses was not affected by treatment with oFF or control serum.

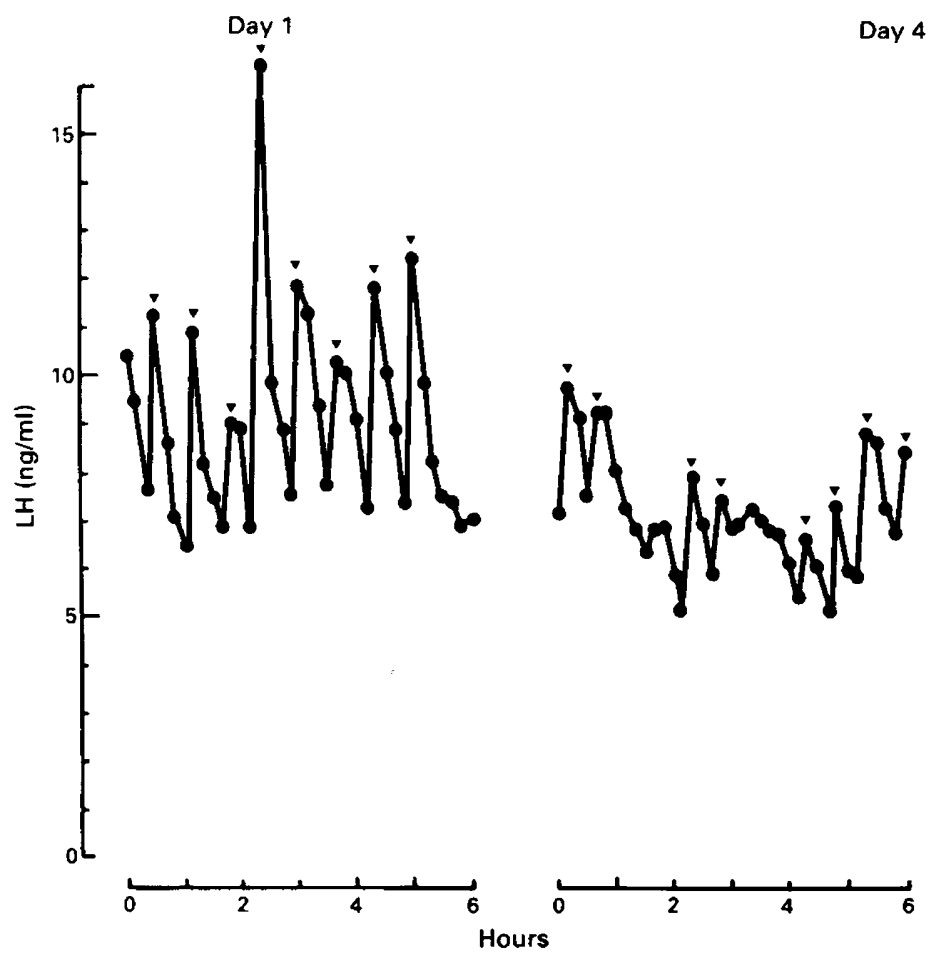

Fig. 1. Plasma LH concentrations before (Day 1) and after (Day 4) control serum treatment of an ovariectomized ewe from Exp. 2a: $\nabla$ indicates a significant pulse as defined in 'Materials and Methods'.

Experiment $2 b$. Treatment with control serum had no significant effect on the values measured. Treatment with oFF caused a significant $(P<0.005)$ reduction in plasma FSH concentrations (Fig. 2). Also, relative to the change in control animals, oFF treatment caused a significant $(P<0.005)$ reduction in mean $\mathrm{LH}$ concentrations. There was no significant effect of oFF on plasma LH pulse amplitude; this result was weighted by 1 ewe in which the amplitude rose from $4.6 \pm 0.9$ (s.e.m.; 7 pulses) to $8.1 \pm 0.8$ ( 5 pulses) $\mathrm{ng} / \mathrm{ml}$ whereas reductions were seen in 3 other animals. Mean \pm s.e.m. values for these 3 animals were $4.6 \pm 0.9 \mathrm{ng} / \mathrm{ml}$ on Day 1 and $2.1 \pm 0.3 \mathrm{ng} / \mathrm{ml}$ on Day 4 ( $P<0.005$ compared to the change in control serum-treated ewes). Intervals between pulses were unaffected by oFF treatment. 


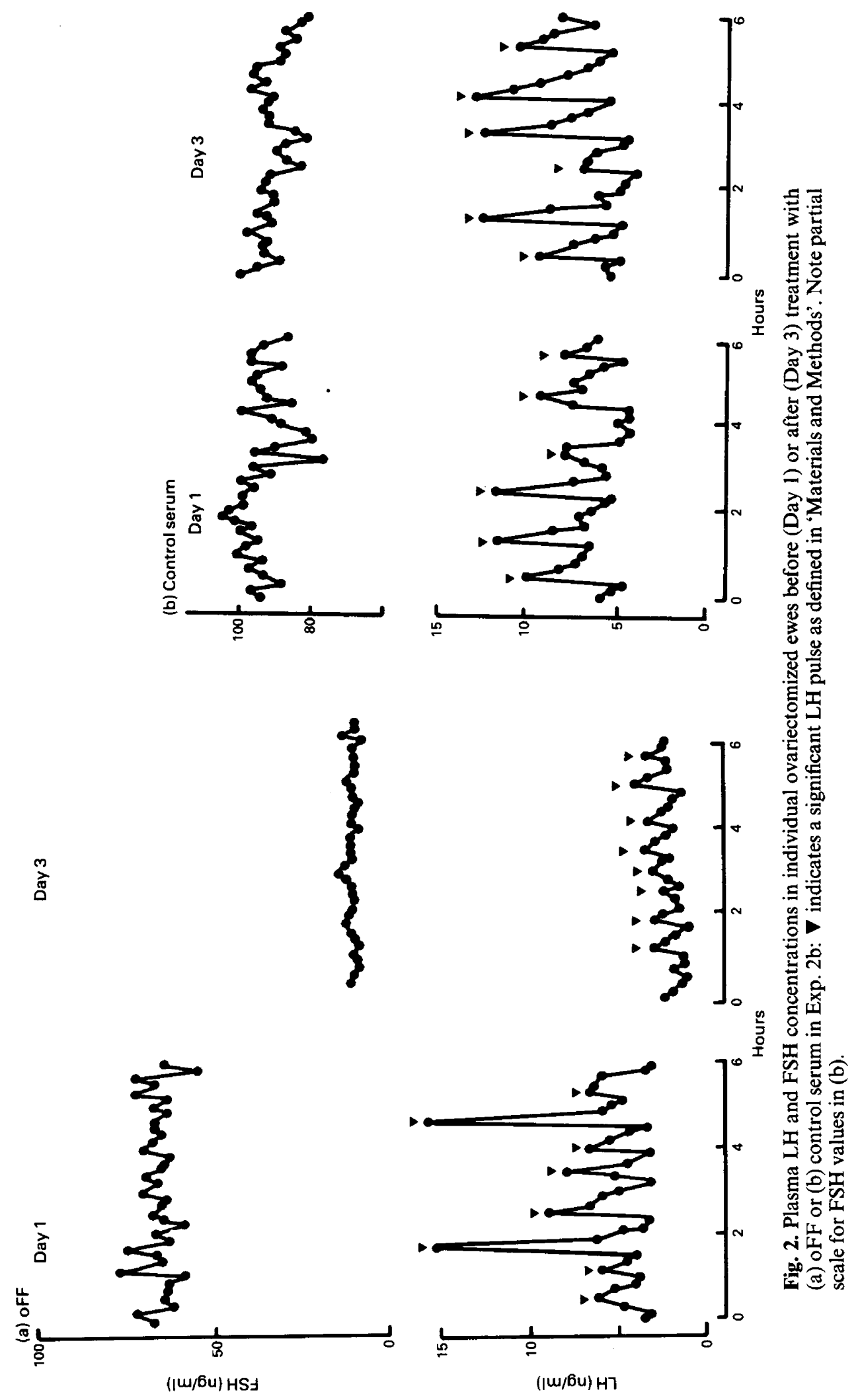


Table 3. Effects of oFF and control serum on mean \pm s.e.m. plasma FSH concentrations and plasma LH pulse amplitudes in ovariectomized ewes given $250 \mathrm{ng}$ pulses of GnRH every $2 \mathrm{~h}$

\begin{tabular}{|c|c|c|c|c|}
\hline \multirow[b]{2}{*}{ Day of exp. } & \multicolumn{2}{|c|}{$\begin{array}{l}\text { Control serum-treated ewes } \\
\qquad(N=4)\end{array}$} & \multicolumn{2}{|c|}{$\begin{array}{l}\text { oFF-treated ewes } \\
\quad(\mathrm{N}=3)\end{array}$} \\
\hline & $\begin{array}{l}\text { LH pulse amplitude } \\
\qquad(\mathrm{ng} / \mathrm{ml})\end{array}$ & $\begin{array}{l}\text { FSH } \\
(\mathrm{ng} / \mathrm{ml})\end{array}$ & $\begin{array}{l}\text { LH pulse amplitude } \\
\qquad(\mathrm{ng} / \mathrm{ml})\end{array}$ & $\underset{(\mathrm{ng} / \mathrm{ml})}{\mathrm{FSH}}$ \\
\hline $\begin{array}{l}1 \text { (no treatment) } \\
2 \\
3 \\
4\end{array}$ & $\begin{array}{l}7 \cdot 5 \pm 1 \cdot 3 \\
8 \cdot 0 \pm 1 \cdot 1 \\
8.5 \pm 1 \cdot 6 \\
7 \cdot 1 \pm 1 \cdot 5\end{array}$ & $\begin{array}{l}58 \pm 3 \\
59 \pm 2 \\
60 \pm 3 \\
63 \pm 2\end{array}$ & $\begin{array}{l}7 \cdot 8 \pm 1 \cdot 0 \\
6 \cdot 6 \pm 1 \cdot 0 \\
5 \cdot 4 \pm 1 \cdot 3^{* *} \\
5 \cdot 3 \pm 0 \cdot 7^{*}\end{array}$ & $\begin{array}{l}43 \pm 6 \\
10 \pm 1^{* * *} \\
3 \pm 1^{* * *} \\
2 \pm 1^{* * *}\end{array}$ \\
\hline
\end{tabular}

${ }^{*} P<0.05,{ }^{* *} P<0.01,{ }^{* * *} P<0.005$, compared with value for controls at the same time.
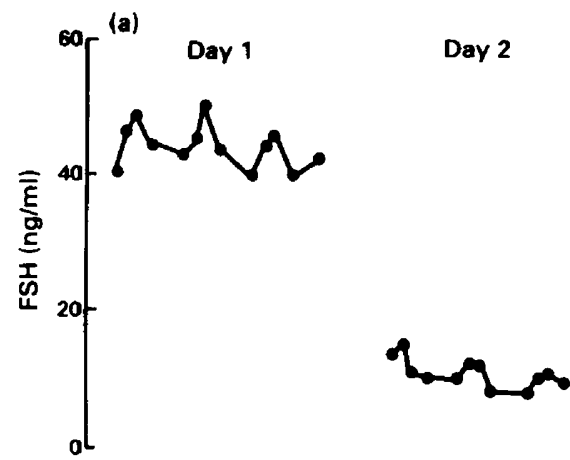

Day 3

Day 4
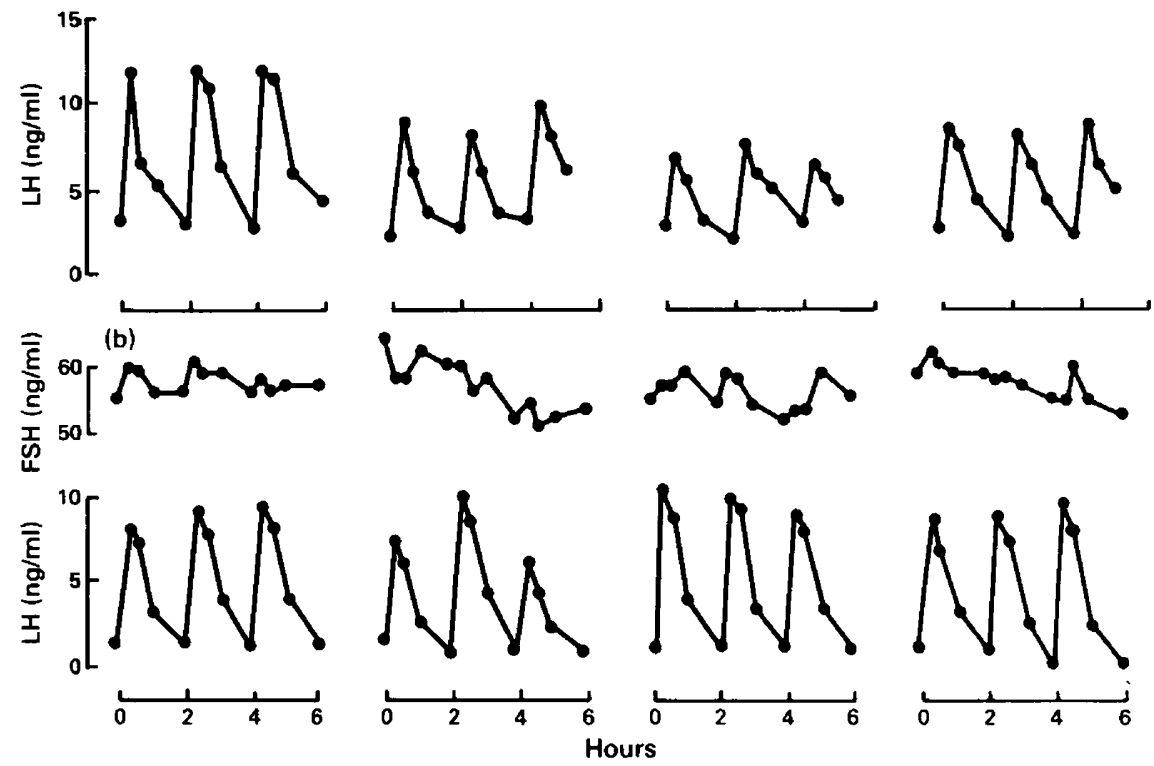

Fig. 3. Plasma LH and FSH concentrations in ovariectomized ewes with a hypothalamopituitary disconnection given $250 \mathrm{ng}$ pulses of GnRH every $2 \mathrm{~h}$, showing the effects of (a) oFF or (b) control serum in individual animals from Exp. 3. Note partial scale for FSH values in (b). 


\section{Experiment 3: direct pituitary effects of oFF}

Treatment with control serum did not cause a significant alteration in plasma FSH concentrations and there was no significant change in plasma LH pulse amplitude (Fig. 3). Treatment with oFF caused a significant $(P<0.005)$ reduction in FSH values within 1 day and a significant $(P<0.01)$ reduction in plasma LH pulse amplitude within 2 days. While FSH values fell by $95 \%$ over 2 days, the LH values fell by $32 \%$.

\section{Discussion}

These studies show that the major effect of inhibin is to reduce FSH secretion by action on the pituitary gland. Since oFF treatment did not affect LH pulse frequency, it may be concluded that inhibin does not act on the hypothalamic or extrahypothalamic centres that determine GnRH pulse frequency. The weight of evidence presented in the present paper suggests that components of oFF can affect LH pulse amplitude, probably by a direct pituitary action.

The in-vivo data presented herein verify that ovine follicular fluid is a potent source of inhibin (Cummins, O'Shea, Bindon, Lee \& Findlay, 1983; Findlay et al., 1985). Similar results have been obtained using follicular fluid in rats (de Jong \& Sharpe, 1976; Marder, Channing \& Schwartz, 1977; Hermans, van Leeuwen, Debets \& de Jong, 1980; Hermans, Debets, van Leeuwen \& de Jong, 1981; de Greef et al., 1983). Our experiments show that FSH secretion can be virtually stopped by ovine follicular fluid in GnRH-pulsed ovariectomized ewes with a hypothalamo-pituitary disconnection, indicating that a hypothalamic action is not obligatory for inhibin action. Our data do not support the previous findings of Lumpkin et al. (1981) and Condon et al. (1983) indicating that inhibin has a selective effect on FSH secretion via a hypothalamic mechanism. It does remain possible that inhibin could affect the release of a separate FSH releasing factor that has been postulated (Chappel \& Barraclough, 1976) but not identified.

Various studies have shown that follicular fluid preparations may reduce plasma LH concentrations during the periovulatory period in rats (DePaolo, Schander, Wise, Barraclough \& Channing, 1979; Rush et al., 1981) or male rats after castration (de Jong \& Sharpe, 1976). Others have reported enhancement of LH secretion after follicular fluid treatment (Bronson \& Channing, 1978; Miller, Wesson \& Ginther, 1979; Wallace \& McNeilly, 1985) and some have reported no change (Hoffman, Lorenzen, Weil \& Schwartz, 1979; Campbell \& Schwartz, 1979; de Greef et al., 1983). In ovariectomized ewes Cummins et al. (1983) found a slight suppression of plasma LH after 3 days of oFF treatment. Findlay et al. (1985) reported that average LH concentrations could be reduced by high doses of oFF but the statistical methods used did not indicate significant trends. For the present study we have used a more rigorous statistical analysis and a more frequent sampling schedule and found that oFF can cause a significant reduction in LH secretion. This effect was noticed in Exp. $2 b$ and was probably due to a reduction in LH pulse amplitude, which occurred in 3 of 4 animals. The variable patterns of the $\mathrm{LH}$ responses to oFF ( 1 sheep showed an increased amplitude) indicate the fickle nature of the LH secretory mechanisms with regard to follicular fluid proteins. Similarly inconsistent results have been achieved in rats by Charlesworth et al. (1984), who explained their results in terms of varying backgrounds of GnRH stimulation.

With particular reference to the sheep, the present results and those of Cummins et al. (1983) and Findlay et al. (1985), all studies with ovariectomized ewes, differ from those obtained by Wallace \& McNeilly (1985), who observed increased LH pulse frequency and amplitude in ewes treated with bovine follicular fluid during the luteal phase of the oestrous cycle. Results with intact ewes are confounded by the effects of ovarian steroids; for example, follicular fluid can reduce plasma FSH concentrations which could in turn reduce oestrogen production from the ovarian follicles (see review by Baird, 1983) leading to a lessening of the negative feedback effect on 
GnRH/LH secretion. Since our experiments were not affected by ovarian steroids we were able to ascertain the direct effects of ovine follicular fluid on gonadotrophin secretion.

We found that oFF did not affect LH pulse frequency but did exert a maximal effect on FSH secretion. Therefore, any effect on GnRH output would necessitate a reduction in GnRH pulse amplitude. Although we possess a conscious animal model to measure GnRH secretion we cannot compare the GnRH pulse amplitudes in different sheep (Clarke \& Cummins, 1985), and so we do not have a direct way of measuring oFF effects on GnRH pulse amplitude. In the present study we have used an indirect method, that of the sheep with a hypothalamo-pituitary disconnection, and examined the exclusive pituitary action. We account for the reduced LH pulse amplitude seen after oFF treatment of ovariectomized ewes by a pituitary effect of inhibin because a reduction in LH pulse amplitude was seen in GnRH-pulsed, oFF-treated sheep that had been ovariectomized and had a hypothalamo-pituitary disconnection. However, an additional effect on GnRH pulse amplitude cannot be ruled out.

It appears that this effect on LH pulse amplitude is by a mechanism(s) different from those responsible for inhibiting FSH secretion. In general, any hormonal influence that affects both gonadotrophins, e.g. oestrogen, has a more rapid effect on LH than on FSH (Clarke, Funder \& Findlay, 1982). In oFF-treated ewes the reverse was noted in Exp. 3 in which an FSH effect was obtained within 1 day but an LH effect was not obtained until 2 days of treatment. This supports the view that inhibin acts selectively on FSH secretory mechanisms, particularly at lower doses of oFF (Findlay et al., 1985).

In the course of one of our experiments (Exp. 2a) we observed a non-specific reduction in the LH pulse amplitude of control ewes treated with serum from an hypophysectomized ewe. These sheep had been recently removed from pasture and placed in individual pens and subjected to a change in diet; we suspect that one or all of these factors were responsible for the observed reduction in LH output. A similar effect was not observed when sheep were conditioned to the experimental environment.

In conclusion we have shown that the action of inhibin to regulate FSH secretion can be accounted for by pituitary action. Inhibin or other follicular fluid proteins do not affect $\mathrm{GnRH} / \mathrm{LH}$ pulse frequency but may affect LH pulse amplitude. We argue that the latter is probably due to a pituitary effect.

We thank Kathy Burman, Bruce Doughton, Trevor Gill and Paul Weston for technical assistance; the Director of the Animal Research Institute, Victorian Department of Agriculture, Werribee, for the use of facilities; NIADDK for hormones for iodination and assay standards; Dr David Robertson for the inhibin bioassays; and Diane Hollingsworth and Anne Saunders for preparing the manuscript. This work was supported by the National Health and Medical Research Council of Australia.

\section{References}

Baker, H.W.G., Bremner, W.J., Burger, H.G., de Kretser, D.M., Dulmanis, A., Eddie, L.W., Hudson, B., Keogh, E.J., Lee, V.W.K. \& Rennie, G.C. (1976) Testicular control of follicle stimulating hormone secretion. Recent Prog. Horm. Res. 32, 429-475.

Baird, D.T. (1983) Factors regulating the growth of the preovulatory follicle in the sheep and human. $J$. Reprod. Fert. 69, 343-352.

Bremner, W.J., Findlay, J.K., Lee, V.W.K., de Kretser, D.M. \& Cumming, I.A. (1980) Feedback effects of the testis on pituitary responsiveness to LHRH infusions in the ram. Endocrinology 106, 329-336.

Bronson, F.H. \& Channing, C.P. (1978) Suppression of serum follicle-stimulating hormone by follicular fluid in the maximally estrogenized ovariectomized mouse. Endocrinology 103, 1894-1898.

Burger, H.G., Lee, V.W.K. \& Rennie, G.C. (1972) A generalised computer program for the treatment of data from competitive binding assays including radioimmunoassays. J. lab. clin. Med. 80, 302 312.

Campbell, G.S. \& Schwartz, N.B. (1979) Time course of serum FSH suppression in ovariectomized rats injected with porcine follicular fluid (folliculostatin): effects of estradiol treatment. Biol. Reprod. 20, 1093-1098. 
Carson, R.S., Trounson, A.O. \& Findlay, J.K. (1982) Successful fertilisation of human oocytes in vitro: concentration of estradiol-17 $\beta$, progesterone and androstenedione in the antral fluid of donor follicles. J. clin. Endocr. Metab. 55, 798-800.

Chappel, S.C. \& Barraclough, C.A. (1976) Hypothalamic regulation of pituitary FSH secretion. Endocrinology 98, 927-935.

Charlesworth, M.C., Grady, R.R., Shin, L., Vale, W.W., Rivier, C., Rivier, J. \& Schwartz, N.B. (1984) Differential suppression of FSH and LH secretion by follicular fluid in the presence or absence of $\mathrm{GnRH}$. Neuroendocrinology 38, 199-205.

Clarke, I.J. \& Cummins, J.T. (1982) The temporal relationship between gonadotropin-releasing hormone $(\mathrm{GnRH})$ and luteinising hormone (LH) secretion in ovariectomized ewes. Endocrinology 111, 1737-1739.

Clarke, I.J. \& Cummins, J.T. (1985) Increased GnRH pulse frequency associated with estrogen-induced $\mathrm{LH}$ surges in ovariectomized ewes. Endocrinology 116, 2376-2383.

Clarke, I.J., Funder, J.W. \& Findlay, J.K. (1982) A study of the relationships between pituitary nuclear oestrogen receptors and the release of LH, FSH and prolactin in the ewe. J. Reprod. Fert. 64, 355-362.

Clarke, I.J., Cummins, J.T. \& de Kretser, D.M. (1983) Pituitary gland function after disconnection from direct hypothalamic influences in the sheep. Neuroendocrinology 36, 376-384.

Clarke, I.J., Cummins, J.T., Findlay, J.K., Burman, K.J. \& Doughton, B.W. (1984a) Effects on plasma luteinizing hormone and follicle stimulating hormone of varying the frequency and amplitude of gonadotropinreleasing hormone pulses in ovariectomized ewes with hypothalmo-pituitary disconnection. Neuroendocrinology 39, 214-22!.

Clarke, I.J., Findlay, J.K. \& Cummins, J.T. (1984b) In Vivo evidence that the pituitary gland is the main site for the action of inhibin. Proc. 16th Annual Conf. Aust. Soc. Reprod. Biol., Melbourne. Abstract 18.

Condon, T.P., Leipheimer, R.E. \& Curry, J.J. (1983) Preliminary evidence for a CNS site of action for ovarian inhibin. Life Sciences 32, 1691-1698.

Cummins, L.J., O'Shea, T., Bindon, B.M., Lee, V.W.K. \& Findlay, J.K. (1983) Ovarian inhibin content and sensitivity to inhibin in Booroola and control strain Merino ewes. J. Reprod. Fert. 67, 1-7.

de Greef, W.J., de Jong, F.H., de Koning, J., Steenburger, J. \& van der Vaart, P.D.M. (1983) Studies on the mechanism of the selective suppression of plasma levels of follicle-stimulating hormone in the female rat after administration of steroid-free bovine follicular fluid. J. Endocr. 97, 327-338.

de Jong, F.H. \& Robertson, D.M. (1985) Inhibin: 1985 update on action and purification. Molec. cell. Endocr. 42, 95-103.

de Jong, F.H. \& Sharpe, R.M. (1976) Evidence for inhibin-like activity in bovine follicular fluid. Nature. Lond. 263, 71-72.

de Jong, F.H., Smith, S.D. \& van der Molen, H.J. (1979) Bioassay of inhibin-like activity using pituitary cells in vitro. J. Endocr. 80, 91-102.

DePaolo, L.V., Schander, D., Wise, P.M., Barraclough, C.A. \& Channing, C.P. (1979) Identification of inhibin-like activity in ovarian venous plasma of rats during the estrous cycle. Endocrinology 105, 647-654.

Findlay, J.K., Gill, T.W. \& Doughton, B.W. (1985) Influence of season and sex on the inhibitory effect of ovine follicular fluid on plasma gonadotrophins in gonadectomized sheep. J. Reprod. Fert. 73, 329-335.

Hermans, W.P., van Leeuwen, E.C.M., Debets, M.H.M. \& de Jong, F.H. (1980) Involvement of inhibin in the regulation of follicle stimulating hormone concentrations in prepubertal and adult, male and female rats. J. Endocr. 86, 79-92.

Hermans, W.P., Debets, M.H.M., van Leeuwen, E.C.M. \& de Jong, F.H. (1981) Time-related secretion of gonadotrophins after a single injection of steroid-free bovine follicular fluid in prepubertal and adult female rats. J. Endocr. 90, 69-76.

Hoffman, J.C., Lorenzen, J.R., Weil, T. \& Schwartz, N.B. (1979) Selective suppression of the primary surge of follicle-stimulating hormone in the rat: further evidence for folliculostatin in porcine follicular fluid. Endocrinology 105, 200-203.

Karsch, F.J., Foster, D.L., Bittman, E.L. \& Goodman, R.L. (1983) A role for estradiol in enhancing luteinizing hormone pulse frequency during the follicular phase of the estrous cycle of sheep. Endocrinology 113, 1333-1339.

Lee, V.W.K., Cumming, I.A., de Kretser, D.M., Findlay, J.K., Hudson, B. \& Keogh, E.J. (1976) Regulation of gonadotrophin secretion in rams from birth to sexual maturity. J. Reprod. Fert. 46, 1-6.

Lee, V.W.K., Scott, R.S., Dobos, M., Zachariah, E., de Kretser, D.M. \& Burger, H.G. (1979) Inhibin and the biological significance of FSH suppression. In Recent Advances in Reproduction and Regulation of Fertility, pp. 241-252. Ed. G. P. Talwar. Elsevier/North Holland, Amsterdam.

Lee, V.W.K., Quigg, H., McMaster, J., Burger, H.G. \& Leversha, L. (1983) A sensitive and rapid bioassay for inhibin based on inhibition of pituitary gonadotrophin secretion in vitro. Proc. Endocr. Soc. Aust. 26, 32, Abstr.

Lumpkin, M., Negro-Vilar, A., Franchimont, P. \& McCann, S. (1981) Evidence for a hypothalamic site of action of inhibin to suppress FSH release. Endocrinology 108, 1101-1104.

Marder, M.L., Channing, C.P. \& Schwartz, N.B. (1977) Suppression of serum follicle stimulating hormone in intact and acutely ovariectomized rats by porcine follicular fluid. Endocrinology 101, 1639-1642.

McNeilly, A.S. (1984) Changes in FSH and the pulsatile secretion of LH during the delay in oestrus induced by treatment of ewes with bovine follicular fluid. $J$. Reprod. Fert. 72, 165-172.

Miller, K.F., Wesson, J.H. \& Ginther, O.J. (1979) Changes in concentrations of circulating gonadotropins following administration of equine follicular fluid to ovariectomized mares. Biol. Reprod. 21, 867-877.

Rush, M.E., Ashiru, O.A., Lipner, H.I., Williams, A.T., McRae, C. \& Blake, C.A. (1981) The actions of porcine follicular fluid and estradiol on periovulatory secretion of gonadotropic hormones in rats. Endocrinology 108, 2316-2323.

Scott, R.S., Burger, H.G. \& Quigg, H. (1980) A simple 
and rapid bioassay for inhibin. Endocrinology 107, 1536-1542.

Steinberger, A. \& Steinberger, E. (1976) 'Secretion of an FSH inhibiting factor by cultured Sertoli cells. Endocrinology 99, 918-921.

Tsonis, C.G., Quigg, H., Lee, V.W.K., Leversha, L., Trounson, A.O. \& Findlay, J.K. (1983) Inhibin in individual ovine follicies in relation to diameter and atresia. J. Reprod. Fert. 67, 83-90.
Wallace, J.M. \& McNeilly, A.S. (1985) Increase in ovulation rate after treatment of ewes with bovine follicular fluid in the luteal phase of the oestrous cycle. $J$. Reprod. Fert. 73, 505-515.

Received 6 November 1985 